\title{
TYÖPAIKKAKOULUTUKSEN KEHITTÄMINEN
}

Työtehtävien eriytyessä ja ammattitaitovaatimusten kasvaessa syntyy tarvetta koulutuksen järjestämiseen työssä tai välittömästi työhön liittyen. Olennaiset muutokset työprosessissa toteutetaan entistä useammin koulutuksen avulla.
Työntekijöiden siirtyminen työstä toiseen yrityksen sisällä lisääntyy, jos työllisyys säilyy nykyisellä tasollaan.

Merkittävä osa työntekijöistä pitää parhaana koulutusmuotona sellaista, jossa työ ja koulu- 
tus yhdistyvät. SAK:n viime kevään koulutustiedustelussa liki kolmannes vastaajista piti parhaana koko- tai osapäiväistä opiskelua työpaikalla.

Perinteisesti meillä työpaikkakoulutukseksi on katsottu oppisopimuskoulutus. Tulevaisuudessa tarvitaan uusia keinoja työn ja koulutuksen yhteenliittämiseen. Erityisen tärkeä on avata aikuisille mahdollisuus yksilöllisiin koulutusohjelmiin, joissa työnteko ja koulutus vuorottelevat.

Opetusministeriön työryhmä valmisteli työpaikkakoulutusta koskevan lainsäädännön kehittämistä. Työryhmä esitti hallinnon uudistamista siten, että työpaikkakoulutuksen hallinto siirtyy oppilaitoksille. Samalla nimikkeitä uudistettiin: oppisopimuksesta tuli "'työpaikkaopiskelu".

Merkittävin esitys oli väliaikaisena toteutetun ns. koulutussopimuskoulutuksen vakinaistaminen.

Työryhmän esitykset saivat ristiriitaisen vastaanoton ja asia - jälleen kerran — hautautui.

\section{Työpaikkakoulutuksen luonteesta}

Eriytyvä työelämä edellyttää, että nuorten saama ammatillinen koulutus pitää sisällään entistä enemmän käytännön työhön orientoivaa toimintaa varsinaisen laaja-alaisen ammattiteoreettisen koulutuksen lisäksi. Koulutusaikainen työharjoittelu voi tukea myös nuorten opiskelumotivaatiota.

Työhön suuntaava osuus opetuksessa voi olla ennakko-, väli- tai jälkiharjoittelua, työnopetusta työpaikalla tai ammatinvalinnallisesti suuntautunutta työhön perehtymistä tai työkokeiluja.

Sen sijaan ei ole tarkoituksenmukaista, että osa ikäluokasta tulee työelämään ilman laajaa ammattiteoreettista pohjakoulutusta, kuten nykyisin on tilanne nuorten oppisopimuskoulutuksessa.

Maissa, joissa ammatillinen koulutus tapahtuu työpaikoilla, nuorisotyöttömyys on ongelma. Työelämän suhdannevaihtelut heijastuvat koulutukseen. Taloudellisesti hyvinä aikoina koulutusta järjestetään, mutta huonoina aikoina koulutusta supistetaan.

Työelämän koulutusintensiivisyyden kasvaessa pelkän työpaikkakoulutuksen varassa työelämään tulleet ovat vaikeuksissa. Erityisesti muutostilanteissa tarvitaan laajempaa ammattiteoreettista ja yleissivistävää koulutuspohjaa.

Samanaikaisesti myös ammattirakenne kehittyy suuntaan, joka suosii perusammattikou- lutetun työvoiman asettamista etusijalle työhönotossa: pelkästään työssä opittavia työtehtäviä on tarjolla entistä vähemmän.

Nuorten perusammattikoulutuksena toteutettava oppisopimuskoulutus on onneksi meillä voimakkaasti vähentynyt. Sen sijaan on kasvanut aikuisten työpaikkakoulutus.

\section{Koulutussopimuskoulutuksen kehittämistavoitteista}

Lähtökohtana tulisi pitää pyrkimystä ohjata mahdollisimman suuri osa ikäluokasta ammatillisesti eriytyneeseen koulutukseen. Tämä edellyttää sitä, että kouluilla on mahdollisuus organisoida nykyistä työvaltaisempaa koulutusta ja tarvittaessa harjoittelua niille nuorille, jotka haluavat peruskoulun jälkeen suoraan työelämään.

Tämä tarkoittaisi koulutussopimusjärjestelmän kehittämistä nykyistä joustavammaksi. Työpaikkakoulutuksen osuus voisi koulutusammateittain vaihdella. Koulutustavoitteet olisivat kuitenkin aina keskiasteen muita ammattitutkintoja vastaavat ja johtaisivat samaan jatkoopintokelpoisuuteen.

Aikuisille koulutussopimuskoulutuksen laajentaminen avaisi erinomaisen mahdollisuuden organisoida koulutus siten, että aikuislinjoilla oppilaitoksen järjestämä koulutus ja työ voisivat vuorotella.

\section{Nykymuotoisen oppisopimuskoulutuksen kehittäminen}

Erityisesti vähän koulutetuilla aikuisilla on vaikeuksia kokonaan irtautua työstä uudelleenkoulutusta varten. Kokopäiväinen opiskelu on raskasta ja toisaalta epävarmuus tulevasta työstä ohjaa motivaatiota enemmän työnhakuun kuin ammattitaidon kehittämiseen.

Juuri keski-ikäisten työntekijöiden joustavien koulutusmahdollisuuksien kehittäminen on eräs avainkysymys tulevaisuuden työvoimatarpeiden ja muutostilanteiden hallinnan kannalta. Taloudellisen turvallisuuden lisäksi tarvitaan turvallinen ja likeinen koulutustapa.

Työsuhteessa tapahtuva ammatillinen uudelleenkoulutus ( $\mathrm{ja}$ eräiltä osin myös täydennyskoulutus) voisi tapahtua rakennemuutostilanteissa osittain nykyisen kaltaista oppisopimusjärjestelmää hyväksikäyttäen. Muotona työn ja koulutuksen integrointi sopii erinomaisesti aja- 
tukseen joustavasta, yksilön oppimisedellytyksistä lähtevästä koulutuksesta. Se on liitettävissä tutkintojärjestelmään, jolloin muoto tarjoaa mahdollisuuden yksilölliseen etenemiseen.

Uudet koulutuksen rahoitusjärjestelmät puolestaan edesauttavat sitä, että koulutukseen voi ohjautua niin työllisyyssyistä, omaehtoisesti kuin työnantajan lähettämänäkin.

\section{Miten eteenpäin?}

On vahinko, että työpaikkakoulutustyöryhmän esitykset "'ammuttiin alas" lähinnä sellaisilla argumenteilla, joilla ei ollut juurikaan yhteyttä työryhmän esityksiin. Vannoutuneet oppisopimuskoulutuksen kannattajat ryhtyivät puolustamaan lempilastaan pelottelemalla työhön liitettävän koulutuksen loppumisella.
Työryhmän esitykset tähtäsivät kuitenkin päinvastaiseen: koulutussopimuskoulutuksen laajentaminen olisi tuonut kymmeniä tuhansia pelkän oppilaitoskoulutuksen saavia työharjoittelun ja työpaikalla tapahtuvan työnopetuksen piiriin. Oppilaitosten vastuulle siirretty työpaikkakoulutus olisi saanut piiriinsä kymmeniä tuhansia aikuisopiskelijoita, jotka eri tavoin työn ja koulutuksen yhteennivomalla olisivat voineet luoda itselleen sopivan ja toimivan koulutusohjelman.

Työryhmän esitysten suuntaan tullaan kulkemaan joka tapauksessa. Siihen ei koulutusmuotojen erillisyys ratkaisevasti vaikuta. Se kuinka kauan erillishallinto säilyy - ja koulutustarkastajat pysyvät itsenäisissä viroissaan - on onneksi koulutuksen kehittämisen kannalta sivuseikka.

\section{JARI-PEKKA JYRKÄNNE}

